Univerzitet u Beogradu
Poljoprivredni fakultet
Institut za poljoprivrednu tehniku
Naučni časopis
POLJOPRIVREDNA TEHNIKA
Godina XLVI
Broj 1, 2021.
Strane: $63-73$
Faculty of Agriculture

UDK: 665.3; 631.30

\title{
MATLAB OPTIMIZATION OF PRODUCTION UNIT OF A MANUFACTURING FIRM
}

\author{
Ntunde Dilibe Ifeanyi* ${ }^{* 1}$ \\ ${ }^{1}$ Department of Mechanical Engineering, Michael Okpara University \\ of Agriculture, Umudike, Abia State, Nigeria.
}

\begin{abstract}
This research work focused on how to maximize the profit of a mechanical manufacturing firm by optimizing the production units using MATLAB. This numerical analysis was manually done through the Simplex Method to model the production units into a linear mathematical equation that produces four major units which include standard aluminium spoon, bowl, pot and plates. Thereafter, a mathematical model was simulated using MATLAB2013b computational tool based on the previous input data of the mechanical firm and subjected to constraint equations based on the time required to finish each of the three products denoted $\mathrm{p}, \mathrm{q}, \mathrm{r}$ and $\mathrm{s}$. The profit function was subsequently analysed to obtain the quantity of each product that will give maximum profit. The results of the manually calculated linear model corresponded with the MATLAB simulation that revealed that approximately $<1$ units, 17 units, 10 and 8 units of spoon, bowl, grinding teeth plate and pot respectively will have to be produced per day in order to obtain a maximum daily and monthly profit of \#6,120.00 and $\# 134,640.00$. Businesses can thus be optimized and made more lucrative when resources and time available are allocated properly.
\end{abstract}

Keywords: Optimization, production units, profit, mechanical firm

\section{INTRODUCTION}

Engineering firms involving production where the objectives of a firm are centred on the increment in profit and reduction in the cost of production, it becomes imperative to evaluate the equivalent units of production that favours the company's goal.

\footnotetext{
* Corresponding Author. Email address: dilibedilis@gmail.com
} 
Mathematical programming is a technique for solving certain kinds of problems (notably maximizing the profits and minimizing costs) subject to constraints on resources, capacities, supplies, demand and the like (Bender, 2000). The mathematical tools for attaining profitability index are of varying forms such as economic order quantity, break even method, and optimization techniques to mention but a few from several. The data obtained with respect to the formulated model will determine the technique to be utilized (Ejiko et al., 2015). The application of linear programming techniques into the production of Aluminium components through casting will go a long way in the expansion of the workshop activities (Champion Blacksmith Ltd. Foundry Workshop) knowing very much that Aluminium is one of the most abundant metals on earth (Abass, 2000). The basic processes such as mould preparation, pouring and solidification and finishing were considered against the time for varying products such as aluminium spoon, 5 litre bowl, aluminium grinding teeth and 5 litre pot with respect to the available time per day.

The case study of foundry shop largely depends on Aluminium alloy for casting which has properties such as compressive strength, corrosion resistance, fatigue strength, creep strength to mention but a few is used in metal casting (Abass, 2000).

This is a liquid shaping process in which the liquid is made to conform to a desired geometry in a mould and then allowed to transform into a solid (Degarmo et al., 2003; American Foundry society, 2010). The case of solidification as treated by which implies that the transport mechanism, kinetics of heat, fluid and mass flow during liquid to solid transformation of the alloy directly control the resultant cast structure which dictates the properties and performance of the cast components (Beeley, 2001; American Foundry Society, 2010). At the end of simulation process, the numbers of component obtained will go a long way in optimizing the objectives of the company. This tool is not limited to production process only; it can also be applied to other social function in life provided the initial modelling conditions are met. Linear programming (L.P.) is a tool for solving optimization problems. It is a mathematical tool (model) for determining the optimal (maximum or minimum) value of a given function called the objective function, subject to a set of stated restrictions, or constraints, placed on the variable concerned (Joglekar \& Ford, 2005). Also, optimization can be referred to as the act of obtaining the best result under given circumstances. Again, it can be defined as a process of finding the conditions that give the maximum or minimum value of a given function (Bender, 2000).

In the World War II, when the war operations had to be planned to economise expenditure, maximise damage to the enemy, linear programming problems came to the forefront. The first problem in linear programming was formulated in 1941 by the Russian mathematician, L. Kantorovich and the American economist, F. L. Hitchcock, both of whom worked at it independently of each other. This was the well-known transportation problem. In 1945, an English economist, G. Stigler, described yet another linear programming problem - that of determining an optimal diet. In 1947, the American economist, G. B. Dantzig suggested an efficient method known as the Simplex method which is an iterative procedure to solve any linear programming problem in a finite number of steps. With the advent of computers and the necessary software, it has become possible to apply linear programming model to increasingly complex problems in many areas (Joglekar \& Ford, 2005). The method is simple and very powerful algorithm in solving real world problems relating to linear programming. 
The L.P. is a tool for project evaluation and selection which we adopt for decision aiding model. There are various project selection model for deriving varying solutions such as that of economic-batch/lot size, payback period and regression analysis (Adejuyigbe, 2002).

Firms must develop strategies for reassessing the use of their resources in other to survive. Every allocation of resources is an investment in the future. Old techniques such as arithmetic forecast technique (manual calculations), oral guess and unplanned forecast used in the allocation of limited resources in the company are becoming redundant, less efficient, time consuming, obsolete and very lax.

This techniques had slowed down engineering production in the Company as the manual forecast technique must first be carried out before actual production at some points, they do not engage in caring out a forecast to ensuring that limited resources are not wasted or underutilized, thereby increasing production cost, wasting human energy, overstaffing of a particular department and importantly, decrease in monthly profit.

Limited-resource allocation algorithms deal with a difficult problem that mathematicians refer to as a large combinatorial problem. Various approaches have been formulated to solve the problem optimally, including Integer Programming, branch-andbound, and Dynamic Programming. However, none of these were computationally tractable for any real-life problem size, rendering them impractical. The application of linear optimization tool will go a long way in evaluating the economic viability of the company. Linear Optimization/Programming with MATLAB as applied to a Mechanical Industry does not only help in the allocation of limited resources such as to determine the number of components to be produced but also, be employed to determine the number of workers to be employed and the capacity of equipment to be purchased. Thus, the aim of this Project is the MATLAB Optimization of Production Units of a Mechanical firm so as to maximize profit. The objective of the research work is to Optimize the Production Unit of a Manufacturing Firm using MATLAB.

\section{MATERIALS AND METHODS}

The Foundry mechanical Firm selected as the case study produces three major units/components which include aluminium spoon, 5 litre bowl, grinding teeth plate and 5 litre pot by casting. Data were collected during the workshop operation. Time of varying operations were determined by the use of stop watch through observation and monitoring of the product processes which includes moulding, casting and finishing. The data gathered, as shown in Table 1, gives the average moulding time of 20 minutes, 30 minutes, 20 minutes and 30 minutes; casting time of 10, 10, 40 and 30 minutes; and finishing time of 10, 20, 10 and 10 minutes for the aluminium spoon, 5 litre bowl, aluminium grinding teeth and 5 litre pot respectively. 
Table 1: Input data of the production operations in mechanical firm

\begin{tabular}{|c|c|c|c|c|c|c|}
\hline & $\begin{array}{c}\text { Avg.Intial } \\
\text { units }\end{array}$ & $\begin{array}{c}\text { Moulding } \\
\text { (mins) }\end{array}$ & $\begin{array}{l}\text { Casting } \\
\text { (mins) }\end{array}$ & $\begin{array}{c}\text { Finishing } \\
\text { (mins) }\end{array}$ & $\begin{array}{l}\text { Product } \\
\text { per(min) }\end{array}$ & $\begin{array}{c}\text { Profit per } \\
\text { Component } \\
\#\end{array}$ \\
\hline $\begin{array}{l}\text { Aluminium } \\
\text { spoon }\end{array}$ & 10 & 20 & 10 & 10 & 0.25 & 15 \\
\hline 5 litre bowl & 15 & 30 & 10 & 20 & 0.25 & 160 \\
\hline $\begin{array}{l}\text { Grinding } \\
\text { teeth Plate }\end{array}$ & 10 & 20 & 40 & 10 & 0.14 & 180 \\
\hline $\begin{array}{l}5 \text { litre pot } \\
\text { Available } \\
\text { time per day }\end{array}$ & 7 & $\begin{array}{c}30 \\
950\end{array}$ & $\begin{array}{c}30 \\
810\end{array}$ & $\begin{array}{c}10 \\
520\end{array}$ & 0.1 & 200 \\
\hline
\end{tabular}

\section{Formation of the mathematical model of the production unit}

The tabulated data presented in Table 1 was formulated in linear equation to optimize the production unit and increase profit made by the mechanical firm. Hence, let the decision variables be represented as p, q, r and s; these are they units to be optimized stated as follows:

$\mathrm{p}=$ number of aluminium spoon produced in a day

$\mathrm{q}=$ number of 5 litre bowl produced in a day

$\mathrm{r}=$ number of aluminium grinding teeth plate produced in a day

$\mathrm{s}=$ number of 5 litre pot produced in a day

$\mathrm{Z}=$ Profit of the Company to be maximized (to be set as the objective function)

The target is to maximize the company profit. 950,810 and 520 minutes is the available time per day for moulding, casting and finishing. Hence, all parameters needed to formulate the inequalities of the linear programming problem.

The mathematical equations were established as follow:

$$
\begin{array}{rlr}
20 p+30 q+20 r+30 s & \leq 950 \text { (moulding time) } & \ldots \ldots \\
10 p+10 q+40 r+30 s & \leq 810(\text { casting time) } & \ldots \ldots \\
10 p+20 q+10 r+10 s & \leq 520 \text { (finishing time) } & \ldots \ldots \ldots
\end{array}
$$

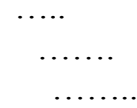

Hence the above equation is subject to the objective function below: $Z=15 p+160 q+180 r+200 s$

These are the constraints, with $p, q, r$ and $s$ as unknowns. $p, q, r, s \geq 0 ; \mathrm{r}, \mathrm{s} 0$; $\mathrm{Z}$ is the profit function to be optimized.

Subsequently, after the manual analysis of the linear equation, the model was mathematically simulated in MATLAB R2013b model, by utilizing the linprog syntax for the system of linear equations expressed in an explicit manner. This method has been successfully implemented for solving a system of four linear equations with three unknowns (variables) and three slack variables (Ejiko, S. O. et al., 2015). 
Therefore, as a logical extension, this study will test the appropriateness of linprog developed codes for a system of four linear equations with four unknowns (variables) and three slack variables on MATLAB to determine the number of Production units ( $p$, $\mathrm{q}, \mathrm{r}$ and $\mathrm{s}$ variables) to be produced in a day and the maximum profit ( $\mathrm{Z}$ ) made in a day. This system of linear equations can be expressed in a matrix form shown in eqn (5).

$$
Z=\left[\begin{array}{c}
a_{41} \\
a_{42} \\
a_{43} \\
a_{44} \\
0 \\
0 \\
0
\end{array}\right]^{T}\left[\begin{array}{c}
p \\
q \\
r \\
s \\
w_{1} \\
w_{2} \\
w_{3}
\end{array}\right]
$$

Where $p, q, r$ and $s$ are the production units and $Z$ is the maximum profit. $T$ indicates e the production units and $\mathrm{Z}$ is the maximum profit. This was solved using linear programming as applied in the mathematically modelling as seen as a function file developed in MATLAB R2013b Interphase shown in Fig 1. This Syntax form the linear equations were used to compare and validate the results of the developed MATLAB simulation model.

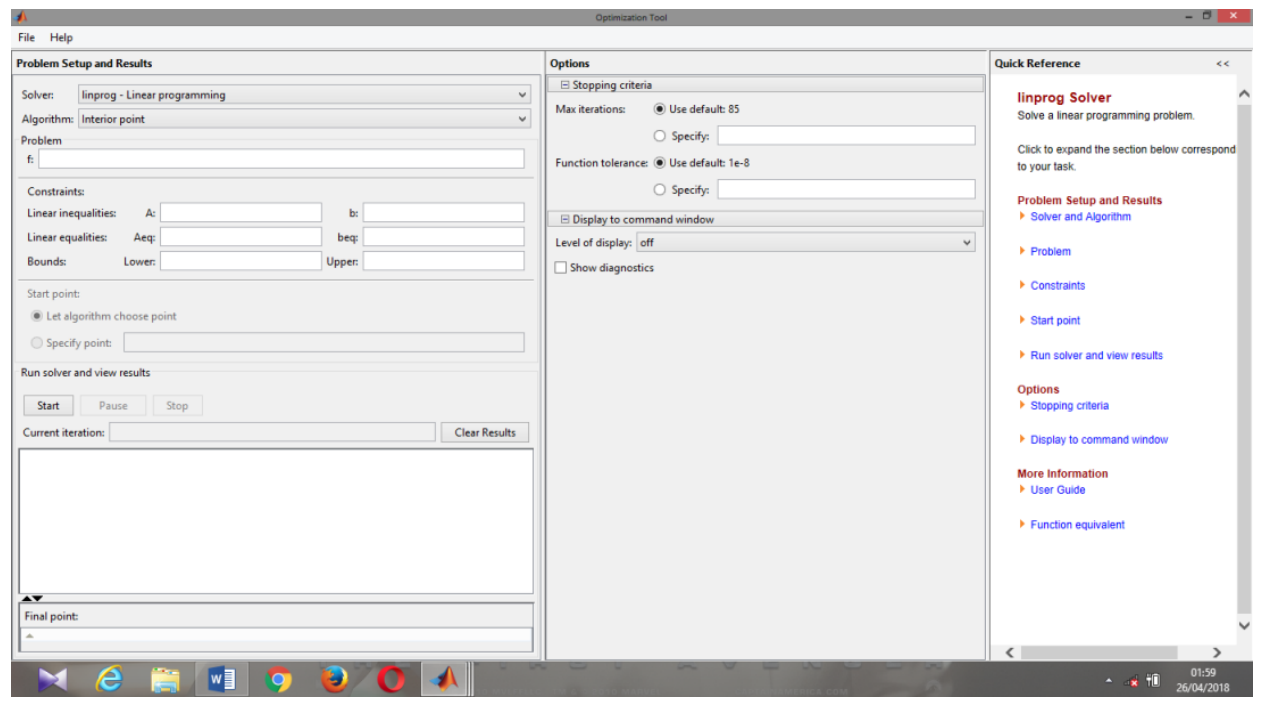

Fig. 1: Interface of Optimization Tool Interphase

\section{RESULTS AND DISCUSSION}

The results of the manual evaluated linear equation Simplex method shown in Table 2 ; and the that of the MATLAB model simulation of the production units shown in Table 3, were developed by establishing the four constraints and seven variables: $p, q, r$, $\mathrm{s}, w_{1}, w_{2}$ and $w_{3}$. If we start by letting $\mathrm{p}, \mathrm{q}, \mathrm{r}$ and $\mathrm{s}$ to be zero, then we have the temporary solutions: $w_{1}=95, w_{2}=81$ and $w_{3}=52$. 
The columns with the slack variable form a unit matrix. The objective function $(Z)$ is moved across the equal sign so as to obtain a function that corresponds to the manual evaluated linear equation.

Table 2: Linear Equation Optimized Results

\begin{tabular}{|c|c|c|c|c|c|c|c|c|c|}
\hline Basis & $P$ & $Q$ & $R$ & $S$ & $w_{1}$ & $w_{2}$ & $w_{3}$ & $b$ & Check \\
\hline$w_{1}$ & 2 & 3 & 2 & 3 & 1 & 0 & 0 & 95 & 106 \\
\hline$w_{2}$ & 1 & 1 & 4 & 3 & 0 & 1 & 0 & 81 & 91 \\
\hline$w_{3}$ & 1 & 2 & 1 & 1 & 0 & 0 & 1 & 52 & 58 \\
\hline$Z$ & $-3 / 2$ & -16 & -18 & -20 & 0 & 0 & 0 & 0 & $-111 / 2$ \\
\hline$w_{1}$ & 2 & 3 & 2 & 3 & 1 & 0 & 0 & 95 & 106 \\
\hline$w_{z} S$ & $1 / 3$ & $1 / 3$ & $4 / 3$ & 1 & 0 & $1 / 3$ & 0 & 27 & $91 / 3$ \\
\hline$w_{3}$ & 1 & 2 & 1 & 1 & 0 & 0 & 1 & 52 & 58 \\
\hline$Z$ & $-3 / 2$ & -16 & -18 & -20 & 0 & 0 & 0 & 0 & $-111 / 2$ \\
\hline$w_{1}$ & 1 & 2 & -2 & 0 & 1 & -1 & 0 & 14 & 15 \\
\hline$w_{z} S$ & $1 / 3$ & $1 / 3$ & $4 / 3$ & 1 & 0 & $1 / 3$ & 0 & 27 & $91 / 3$ \\
\hline$w_{3}$ & $2 / 3$ & $5 / 3$ & $-1 / 3$ & 0 & 0 & $-1 / 3$ & 1 & 25 & $83 / 3$ \\
\hline$Z$ & $31 / 6$ & $-28 / 3$ & $26 / 3$ & 0 & 0 & $20 / 3$ & 0 & 540 & $3307 / 6$ \\
\hline Basis & $p$ & $Q$ & $R$ & $S$ & $w_{1}$ & $w_{2}$ & $w_{3}$ & $b$ & Check \\
\hline$w_{ \pm} q$ & $1 / 2$ & 1 & -1 & 0 & $1 / 2$ & $-1 / 2$ & 0 & 7 & $15 / 2$ \\
\hline$w_{z} S$ & $1 / 3$ & $1 / 3$ & $4 / 3$ & 1 & 0 & $1 / 3$ & 0 & 27 & $91 / 3$ \\
\hline$w_{3}$ & $2 / 3$ & $5 / 3$ & $-1 / 3$ & 0 & 0 & $-1 / 3$ & 1 & 25 & $83 / 3$ \\
\hline$Z$ & $31 / 6$ & $-28 / 3$ & $26 / 3$ & 0 & 0 & $20 / 3$ & 0 & 540 & $3307 / 6$ \\
\hline$w_{ \pm} q$ & $1 / 2$ & 1 & -1 & 0 & $1 / 2$ & $-1 / 2$ & 0 & 7 & $15 / 2$ \\
\hline$w_{z} s$ & $1 / 6$ & 0 & $5 / 3$ & 1 & $-1 / 6$ & $1 / 2$ & 0 & $74 / 3$ & $167 / 6$ \\
\hline$w_{3}$ & $-1 / 6$ & 0 & $4 / 3$ & 0 & $-5 / 6$ & $1 / 2$ & 1 & $40 / 3$ & $91 / 6$ \\
\hline$Z$ & $59 / 6$ & 0 & $-2 / 3$ & 0 & $14 / 3$ & 2 & 0 & $1816 / 3$ & $3727 / 6$ \\
\hline$w_{ \pm} q$ & $1 / 2$ & 1 & -1 & 0 & $1 / 2$ & $-1 / 2$ & 0 & 7 & $15 / 2$ \\
\hline$w_{z} S$ & $1 / 6$ & 0 & $5 / 3$ & 1 & $-1 / 6$ & $1 / 2$ & 0 & $74 / 3$ & $167 / 6$ \\
\hline$w_{3} r$ & $-1 / 8$ & 0 & 1 & 0 & $-5 / 8$ & $3 / 8$ & $3 / 4$ & 100 & $91 / 8$ \\
\hline$Z$ & $59 / 6$ & 0 & $-2 / 3$ & 0 & $14 / 3$ & 2 & 0 & $1816 / 3$ & $3727 / 6$ \\
\hline$w_{ \pm} q$ & $3 / 8$ & 1 & 0 & 0 & $-1 / 8$ & $-1 / 8$ & $3 / 4$ & 17 & $151 / 8$ \\
\hline$w_{3} r$ & $-1 / 8$ & 0 & 1 & 0 & $-5 / 8$ & $3 / 8$ & $3 / 4$ & 10 & $91 / 8$ \\
\hline$w_{z} S$ & $3 / 8$ & 0 & 0 & 1 & $7 / 8$ & $-1 / 8$ & $-5 / 4$ & 8 & $71 / 8$ \\
\hline$Z$ & $39 / 4$ & 0 & 0 & 0 & $17 / 4$ & $9 / 4$ & $1 / 2$ & 612 & $119537 / 1$ \\
\hline
\end{tabular}

The profit function $(Z)$ is calculated manually in order to obtain the quantity of each product that will give maximum profit above. 
The result obtained in Table 2 show that $\mathrm{p}$ - number of spoon is 0 ; $\mathrm{q}$ - number of bowl is 18 units; $r$ - number of teeth plate is 12 units and $s$ - number of pot is 10 units will have to be produced per day in order to obtain a maximum profit of \#6,120.00 in a day.

$\%$ MATLAB Optimization of Production Units of a Foundry Firm using MATLAB:

Case Study \% Of Champion Blacksmith Ltd., Rivers State

$\%$-------- the linprog Syntax is used here in MATLAB

$\%$ In solution, any of the following linprog syntax can be used

$\% \mathrm{x}=\operatorname{linprog}(\mathrm{f}, \mathrm{A}, \mathrm{b})$

$\% \mathrm{x}=\operatorname{linprog}(\mathrm{f}, \mathrm{A}, \mathrm{b}$, Aeq,beq $)$

$\% \mathrm{x}=\operatorname{linprog}(\mathrm{f}, \mathrm{A}, \mathrm{b}, \mathrm{Aeq}, \mathrm{beq}, \mathrm{lb}, \mathrm{ub})$ when specifying the boundaries

$\% \mathrm{x}=\operatorname{linprog}(\mathrm{f}, \mathrm{A}, \mathrm{b}$, Aeq, beq,lb,ub,options)

$\% \mathrm{x}=\operatorname{linprog}($ problem $)$

$\%[\mathrm{x}, \mathrm{fval}]=\operatorname{linprog}(\ldots)$

$\%[\mathrm{x}, \mathrm{fval}, \mathrm{exitflag}, \mathrm{output}]=\operatorname{linprog}(\ldots)$

$\%$ [x,fval,exitflag,output,lambda $]=\operatorname{linprog}(\ldots)$

$\mathrm{f}=[-15-160-180-200] ; \%$ function to be minimized

$\mathrm{A}=[20302030 ; 101040$ 30; 102010 10]; \% left hand side of the constraint equations

$\mathrm{b}=[950 ; 810 ; 520] ; \%$ right hand side of the constraint equations

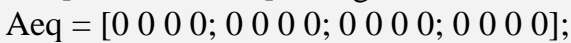

beq $=[0 ; 0 ; 0 ; 0]$;

$\mathrm{lb}=[0 ; 0 ; 0 ; 0]$;

$\mathrm{ub}=$ [inf; inf; inf; inf $]$

$\%$ The first five syntax can be used; the third syntax were boundaries are being

$\%$ specified is simply employed here.

$\mathrm{R}=$ linprog (f,A,b,Aeq,beq,lb,ub) \% perform optimization

$\mathrm{Z}=-\mathrm{f} * \mathrm{R} \%$ compute the maximum profit

Optimization terminated at the followiong:

$\mathrm{R}=0.0000, \quad 18.0000, \quad 12.0000, \quad 10.0000$

$\mathrm{Z}=6.1200 \mathrm{e}+03$

Hence the results indicated show that $\mathrm{R}$ and $\mathrm{Z}$ represent the quantity of each production units in a day and the maximum profit per day, respectively. That implies that, for the firm to achieve an optimal daily profit of $\# 6,120.00 \mathrm{~K}$, it should produce no aluminium spoon, 18 units of 5 litre bowl, 12 units of aluminium grinding teeth plate and 10 units of 5 litre pots.

Subsequently, the results got from the manual computations were the same as that of the manually computed results when the program in Appendix I is run. 
The results shown in shown in Table 3 were gotten from the designed MATLAB program.

$\mathrm{P}=0.0000(<1.0000) ; \mathrm{q}=18.0000 ; \mathrm{r}=12.0000$ and $\mathrm{s}=10.0000$

The maximum profit $\mathrm{z}=\# 6120.00$

Table 3: MATLAB model simulation

\begin{tabular}{|c|l|l|l|l|l|l|l|l|l|}
\hline Basis & $P$ & $Q$ & $R$ & $S$ & $\boldsymbol{w}_{\mathbf{1}}$ & $\boldsymbol{w}_{\mathbf{2}}$ & \multicolumn{1}{|c|}{$\boldsymbol{w}_{\mathbf{3}}$} & $B$ & Check \\
\hline $\boldsymbol{w}_{\mathbf{1}}$ & 2 & 3 & 2 & 3 & 1 & 0 & 0 & 95 & 106 \\
\hline $\boldsymbol{w}_{\mathbf{2}}$ & 1 & 1 & 4 & 3 & 0 & 1 & 0 & 81 & 91 \\
\hline $\boldsymbol{w}_{\mathbf{3}}$ & 1 & 2 & 1 & 1 & 0 & 0 & 1 & 52 & 58 \\
\hline$Z$ & -1.5 & -16 & 18 & -20 & 0 & 0 & 0 & 0 & -55.5 \\
\hline
\end{tabular}

\section{Comparative Analysis of Results}

As seen in Table 2 and Table 3, the results of the manually solve linear equation and that of the MATLAB simulated model are in agreement, where the results show the optimized quantity of product to be produced in order to achieve the maximum profit. The products quantity as estimated includes approximately no units of aluminium spoon (p) per day, 18units of bowl (q) per day and 12 units of aluminium teeth plate (r) per day and 10 units of pot (s) per day with a maximum profit of \#6,120.00. However, the results showed that greater attention should be given to production of bowl because of its volume and profit generated that is almost half of the entire profit and that the company could cease the production of aluminium spoon since no much profit (below 1\%) is got from it as shown in the Pie Chart of Fig. 3. The chart subsequently revealed that the production of 5 litre bowl contributes to $49 \%$ of the Company's viability (growth), grinding teeth plate contributes 29\%; 5 litre pot contributes $23 \%$ to obtain an optimal profit of \#6120.00. Therefore, the company should focus more attention on bowl while also considering the teeth plate and pot as they are more viable than the production of spoon that yields little or no profit.

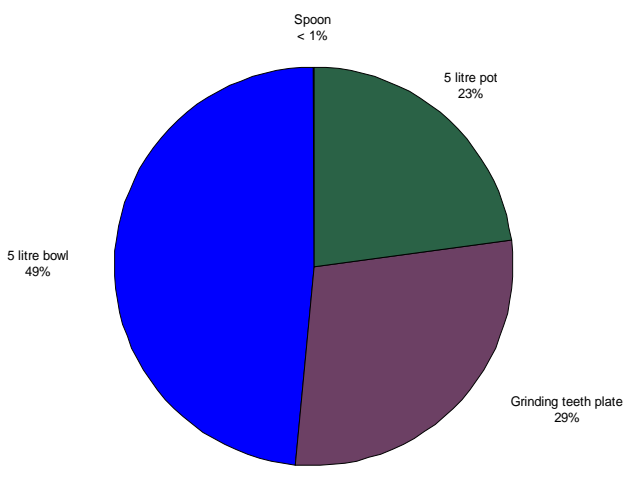

Fig.2. Optimal units of items needed to be produced in a day 
Hence, from the numerical analysis done using MATLAB R2013b, the shaded area shown in Fig. 3 revealed the optimal values of p, q, r, s that yields the optimal profit at the points that are joined linearly to yield a total monthly profit of \#134,640.00.

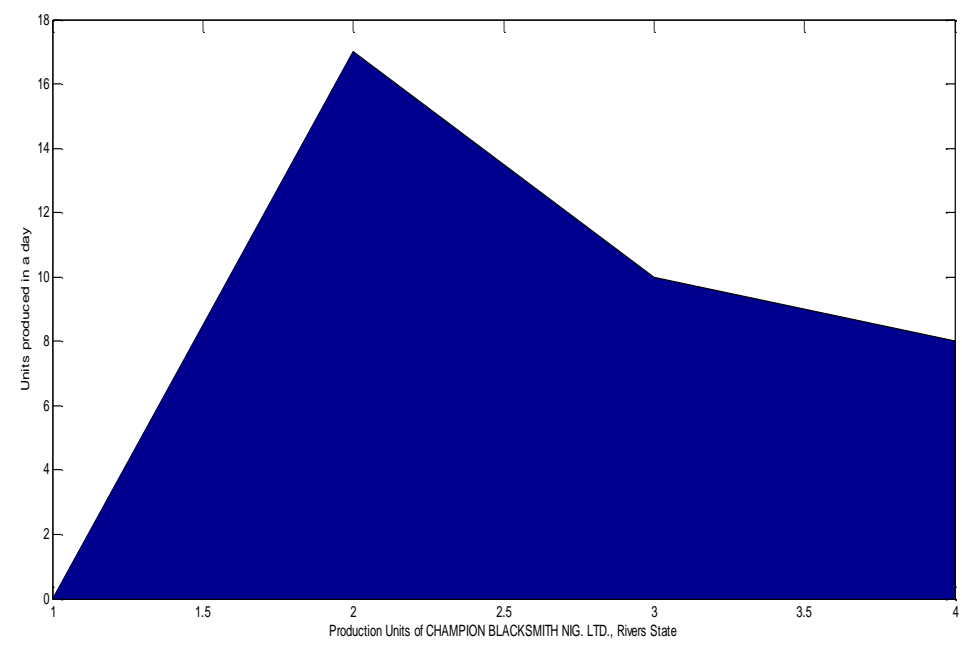

Fig.3. The Area of the Optimal Solution

\section{CONCLUSION}

The Project hence, discusses the possibility of maximizing the profit of the company by optimizing the production units using linear programming under varying constraints in a MATLAB simulation tool.

Produced Units at the Firm include aluminium spoon, 5 litre bowl, grinding teeth plate of aluminium and 5 litre pot respectively, all by casting. Time for varying operations such as moulding, casting (pouring and solidifying) and finishing were collected for each product. The result obtained from the analysed profit function, both manually and by MATLAB simulation program, obtained the quantity of each product that will give maximum profit. These were revealed at approximately $<1$ units, 17 units, 10 units and 8 units of spoon, bowl, grinding teeth plate and pot respectively; should be produced per day in order to obtain a maximum profit of \#6,120.00 in a day for both methods.

The matrix developed is useful in explaining differences in project performance and developing an intuitive understanding of the characteristics and impacts of different allocation policies and techniques. Resource allocation policies were then used in a system dynamics model of the system to test performance. Our results show that and how foresighted policies can improve Production planning performance, without increasing the total amount of resources. While preliminary, our results could have far reaching impacts on resource management through allocation policies because the schedule improvements are essentially free, requiring no additional resources. 
However, not all projects benefit from foresight but these results suggest that an improved understanding for the design of foresighted resource allocation policies are needed to use foresight to improve product development project planning performance.

\title{
REFERENCES
}

[1] Abass, A. O. 2000. Introductory Organic and Inorganic Chemistry, 2nd Edition, Ibadan: OGFAT. pp. 42

[2] Adejuyigbe, S. B. 2002. Production Management (1st ed.). Akure: Topfun Publisher.

[3] American Foundry Society. 2010. Metalcaster's Reference \& Guide. Des Plaines, Illinois: American Foundrymen's Society, Inc. pp. 121.

[4] Anderson, E. G., 2001. The non-stationary staff planning problem with business cycle and learning effects. Management Science Journal. 47 (6), pp. 817-832.

[5] Beeley, P. 2001. Foundry Technology (2nd ed.). Oxford, UK: Butterworth-Heinemann.

[6] Bender, E. 2000. An Introduction to Mathematical Modeling. New York: Dover. pp.12.

[7] Campbell, J.. 2003. Castings (2nd ed.). Oxford, UK: Butterworth-Heinemann.

[8] Degarmo, E. P., Black, J. T., Kohser, R. A. 2003. Materials and Processes in Manufacturing (9th ed.), Wiley, ISBN 0-471-65653-4, pp. 277.

[9] Ejiko, S. O., Adu, J. and Ajewole, P. O. 2015. Optimization of Production Units Using MATLAB Program: A Case Study of the Federal Polytechnic Ado-Ekiti Foundry Shop. Proc. from the OAU Faculty of Technology Conf.. pp. 195-199.

[10] Joglekar, N. R. and Ford, D. N. (2005). Product development Resource Allocation with Foresight. European Journal of Operational Research. (160). pp. 72-87.

[11] Vanderbei, R. J. (2007). Linear Programming: Foundations and Extensions. Springer-Verlag. pp. 111 .

\section{MATLAB OPTIMIZACIJA PROIZVODNE JEDINICE ZA PREDUZEĆE}

\author{
Ntunde Dilibe Ifeanyi \\ Mechanical Engineering Department, Michael Okpara University of Agriculture, \\ Umudike, Abia State, Nigeria
}

Sažetak: Ovaj istraživački rad prikazuje kako postići najveći profit proizvodne firme optimizacijom proizvodnih jedinica pomoću programa MATLAB.

Ova numerička analiza je rađena metodom Simplex kako bi se proizvodne jedinice modelirale kao linearna matematička jednačina koja daje četiri glavne jedinice koje uključuju proizvode kao elemente : standardna aluminijumska kašika, činija, lonac i tanjire.

Nakon toga, matematički model je simuliran upotrebom računarskog alata MATLAB2013b na osnovu prethodnih ulaznih podataka proizvodnog preduzeća i podvrgnut jednačinama ograničenja na osnovu vremena potrebnog za završetak svakog proizvoda označenih sa: $\mathrm{p}, \mathrm{q}, \mathrm{r}, \mathrm{s}$.

Funkcija profita naknadno je analizirana kako bi se dobila količina svakog proizvoda koja donosi najveći profit. 
Rezultati ručno izračunatog linearnog modela korespondiraju sa simulacijom programom MATLAB koja je otkrila da treba dnevno proizvesti približno $<1$ jedinica, 17 jedinica, 10 i 8 jedinica aluminijskih kašika, posuda od 5 lit, ploče, ili lonca od 5 lit., dnevno, kako bi se dobio najveći dnevni i mesečni profit od \#6.120,00 i \#134.640,00.

$\mathrm{Na}$ osnovu prikazanog modela optimizacije, preduzeća se mogu optimizirati i učiniti profitabilnijim, kada se raspoloživi resursi i vreme proizvodnje pravilno rasporede.

Ključne reči: Optimizacija, proizvodna jedinice, profit, mašinsko preduzeće.

Prijavljen:

Submitted:

Ispravljen:

Revised:

Prihvaćen:

Accepted:

23.11.2020.

25.12.2020.

28.01.2021. 